\title{
PERILAKU KREATIF DAN INOVATIF PETANI DALAM USAHA BUDIDAYA BUAH BELIMBING DI KELURAHAN KARANGSARI KECAMATAN SUKOREJO KOTA BLITAR
}

\author{
Defi Rianto ${ }^{1}$, Bambang Suyadi ${ }^{1}$, Titin Kartini ${ }^{1}$ \\ ${ }^{1}$ Program Studi Pendidikan Ekonomi , Fakultas Keguruan dan Ilmu Pendidikan, Universitas Jember \\ e-mail: suyadibambang219@gmail.com
}

\begin{abstract}
Abstrak
Penelitian ini merupakan penelitian kualitatif. Tujuan penelitian ini adalah untuk mendeskripsikan perilaku kreatif dan inovatif petani belimbing dalam membudidayakan buah belimbing di Kelurahan Karangsari Kecamatan Sukorejo Kota Blitar. Teknik pengumpulan data dalam penelitian ini yaitu dengan wawancara langsung kepada 3 informan. Hasil penelitian menunjukkan bahwa ada berbagai macam perilaku kreatif dan inovatif yang dilakukan petani belimbing di Kelurahan Karangsari Kota Blitar. Bapak Imam sebagai informan pertama memiliki perilaku kreatif berinisiatif untuk membuat olahan belimbing. Sikap yang terbuka menjadikan beliau tanggap terhadap kritik dan saran dari para pelanggannya. Perilaku inovatif yang beliau lakukan dengan membuat olahan belimbing. Beliau menerapkan inovasi ukuran produk olahan belimbing dari kecil , sedang, besar dan inovasi berbasis pengurangan upaya. Selanjutnya, Bapak Kawit sebagai informan kedua memiliki perilaku kreatif dengan memiliki ide untuk membuat produk olahan makanan dan minuman baru dari belimbing. Sedangkan perilaku inovatifnya. Beliau juga membuat inovasi kemasan dan inovasi ukuran produk serta inovasi pengurangan upaya. Informan ketiga yaitu Ibu Kholipah memiliki perilaku kreatif untuk memilih mengolah belimbing menjadi produk olahan makanan dan minuman, dibandingkan dengan menjadi tenaga kerja luar negeri seperti yang pernah beliau lakukan. Sedangkan perilaku inovatif yang dilakukan beliau yaitu dengan menerapkan ide kreatif membuah olahan belimbing berupa dodol belimbing, sirup belimbing sari buah belimbing dan manisan belimbing. Beliau juga membuat inovasi ukuran dan inovasi pengurangan buaya. Kesimpulan dalam penelitian ini bahwa terdapat perilaku kreatif dan inovatif petani belimbing di Kelurahan Karangsari Kecamatan Sukorejo Kota Blitar.
\end{abstract}

Kata Kunci: Perilaku Kreatif, Perilaku Inovatif, Petani Belimbing

\section{PENDAHULUAN}

Peluang usaha di Indonesia saat ini tidak hanya berasal dari industri ataupun sektor manufaktur. Tetapi, juga berasal dari sektor pertanian. Salah satu sub sektor pertanian yang dijadikan sebagai peluang usaha baru yaitu sub sektor hortikultura. Potensi yang dimiliki oleh sub sektor hortikultura ini cukup besar. Hasil tanaman hortikultura khususnya untuk buah - buahan, di Indonesia saat ini banyak diminati oleh konsumen. Salah satu buah - buahan holtikultura adalah belimbing.

Buah belimbing mempunyai nama latin Averhoa Carambolo L. Buah yang memiliki bentuk seperti bintang dan lonjong ini, dapat ditemukan diseluruh wilayah Indonesia dan sering dikenal juga dengan istilah Star Fruit. Menurut Prihatman (dalam Tim Penulis PS, 2004:8), belimbing merupakan tanaman buah berupa pohon yang berasal dari kawasan Malaysia, kemudian menyebar luas ke berbagai negara yang beriklim tropis lainnya termasuk Indonesia. Upaya pengembangan telah dilakukan oleh instansi-instansi terkait sehingga mampu menghasilkan beberapa varietas unggulan.

Para petani belimbing tentunya memiliki ide kreatif dan inovatif sebagai dasar untuk selalu mengembangkan usaha belimbingnya. Selain itu, kreatifitas dan inovasi sangat diperlukan agar suatu usaha mampu bersaing dalam dunia bisnis yang perkembangannya tidak bisa kita prediksi. Proses kreatif dan inovatif yang dimiliki para petani belimbing dapat dipengaruhi dari berbagai faktor, baik dari faktor pribadi maupun lingkungan

Berdasarkan observasi yang dilakukan peneliti di Kota Blitar Kecamatan Sukarejo, Kelurahan Karangsari merupakan salah satu sentral petani belimbing yang ada di Kota Blitar. Indikasi tersebut terlihat dari mayoritas penduduk Kelurahan Karangsari yang berprofesi sebagai petani belimbing. Mereka memilih profesi tersebut dikarenakan lahan yang subur untuk dijadikan objek penanaman belimbing. Selain itu, pemerintah 
setempat juga mendukung berbagai kegiatan yang dilakukan oleh petani dikelurahan karangsari tersebut

Produksi belimbing yang semakin meningkat, akan mempertinggi juga tingkat persaingan dikalangan petani belimbing dan mengharuskan petani blimbing untuk memiliki perilaku yang kreatif dan inovatif agar tidak kalah dalam bersaing dengan petani belimbing lainnya.

Dari beberapa petani belimbing yang sudah diobservasi, peneliti melihat adanya perilaku kreatif yaitu menciptakan produk olahan lain dari buah belimbing seperti syrup dan selai. Sedangkan perilaku inovatif yaitu menemukan berbagai variasi rasa produk olahan dari belimbing, seperti opak gambir dari belimbing. Para petani melakukan hal tersebut agar buah belimbing memiliki nilai guna yang tinggi dan untuk menarik konsumen dari dalam maupun luar kota. Meskipun produksi belum tergolong banyak seperti di Jawa Tengah, Namun, belimbing Karangsari sudah berhasil memasuki pasar nasional dan memiliki Brand seperti belimbing Thailand.

Penelitian ini termasuk deskriptif kualitatif. Tujuan penelitian ini adalah untuk mendeskripsikan perilaku kreatif dan inovatif petani belimbing dalam usaha budidaya buah belimbing di Kelurahan Karangsari Kecamatan Sukorejo Kota Blitar. Hasil penelitian ini diharapkan dapat memberikan manfaat bagi wirausahawan dan penelitian yang sejenis terutama dalam bidang kewirausahaan. Adapun manfaat hasil penelitian ini yaitu dapat memberikan informasi tambahan mengenai perilaku kreatif dan inovatif yang harus dimiliki oleh wirausahawan dan dapat dijadikan sumber dan bahan pertimbangan bagi wirausahawan dalam menjalankan kegiatan usahanya.

Berdasarkan latar belakang diatas, maka rumusan masalah dalam penelitian ini yaitu, Bagaimana perilaku kreatif dan inovatif petani dalam usaha budidaya buah belimbing di Kelurahan Karangsari Kecamatan Sukorejo Kota Blitar.

\section{METODE}

Pendekatan yang digunakan dalam penelitian ini adalah pendekatan kualitatif dengan jenis penelitian deskriptif yang bertujuan untuk mendeskripsikan perilaku kreatif dan inovatif petani dalam usaha budidaya buah belimbing di Kelurahan Karangsari Kecamatan Sukorejo Kota Blitar. Penentuan lokasi dalam penelitian ini menggunakan metode purposive area, yaitu di Kelurahan Karangsari Kecamtan Sukorejo Kota Blitar. Penentuan informan dalam penelitian ini diawali dengan penentuan informan utama yang yang berjumlah 3 informan kemudian dilanjutkan dengan penentuan informan pendukung. Metode pengumpulan data dalam penelitian ini berupa metode wawancara, observasi, dan dokumen. Metode analisis data dalam penelitian ini terdiri dari reduksi data, penyajian data, dan penarikan kesimpulan.

\section{HASIL DAN PEMBAHASAN}

Berdasarkan penelitian yang dilakukan oleh penulis tentang Perilaku Kreatif dan Inovatif Petani Dalam Usaha Budidya Buah Belimbing di Kelurahan Karangsari Kecamatan Sukorejo Kota Blitar, menujukkan bahwa petani belimbing di Kelurahan Karangsari menerapkan perilaku kreatif dan inovatif. Ada tiga petani belimbing yang menjadi informan dalam penelitian ini, yaitu Bapak Imam Surani, Bapak Kawit dan Ibu Tri Kholipah. Ketiga Informan tersebut memiliki usaha pengolahan buah belimbing di Kelurahan Karangsari Kecamatan Sukorejo Kota Blitar.

Informan pertama yakni Bapak Imam, melakukan perilaku kreatif dengan tidak hanya menjual buah belimbing segar, tetapi memiliki ide untuk menjadikan belimbing menjadi produk olahan makanan dan minuman, kemudian sikap terbukanya menjadikan beliau untuk tanggap terhadap kritik dan saran yang diberikan oleh pelanggannya. Sedangkan untuk perilaku inovatif yaitu dengan menerapkan ide kreatif untuk mengolah belimbing menjadi dodol belimbing, kerupuk belimbing, syrup belimbing dan manisan belimbing, beliau juga melakukan inovasi berbasis desain berupa label pada produk olahan belimbing., inovasi ukuran , mulai dari kecil, sedang dan besar, inovasi pengurangan untuk mengantisipasi biaya.

Untuk informan kedua yaitu kepada Bapak Kawit. Perilaku kreatif yang dilakukan yaitu dengan memiliki ide untuk membuat produk olahan belimbing berupa makanan dan minuman. Sedangkan perilaku inovatifnya yaitu dengan menerapkan ide kreatif untuk mengolah belimbing menjadi dodol belimbing, syrup belimbing, pangsit belimbing, kripik belimbing, selai belimbing, permen belimbing dan manisan belimbing, 
beliau juga membuat inovasi kemasan dan inovasi ukuran produk serta inovasi pengurangan biaya.

Untuk informan ketiga yaitu kepada Ibu Tri Kholipah. Perilaku kreatif yang dilakukan oleh Ibu Tri Kholipah antara lain dengan memiliki ide untuk membuat olahan belimbing berupa makanan dan minuman, serta beliau memiliki kemampuan memilih untuk menggunakan belimbing sebagai produk olahannya dibandingkan buah lainnya. Sedangkan perilaku inovatifnya yaitu dengan menerapkan ide kreatif untuk membuat olahan berupa dodol belimbing, syrup belimbing, sari buah belimbing dan manisan belimbing, beliau juga membuat inovasi ukuran dan inovasi pengurangan upaya.

Penelitian ini memiliki manfaat tersendiri bagi informan dan penduduk sekitar Kelurahan Karangsari. Bagi informan menjadi lebih mengerti tentang perilaku kreatif dan inovatif yang mereka terapkan serta lebih semangat dalam berwirausaha. Sedangkan bagi penduduk sekitar dapat menjadi salah satu referensi untuk menjadi seorang wirausaha.

Hasil penelitian menunjukkan bahwa ketiga informan memiliki perilaku kreatif dan inovatif yang baik dan mereka mampu menerapkannya konsep kreatif dan inovatif tersebut dilapangan. Konsep kreatif dan inovatif yang dilakukan oleh petani belimbing di Kelurahan Karangsari Kecamatan Sukorejo Kota Blitar sesuai dengan teori Sinaga (2017:35) yang menyatakan bahwa kreatifitas merupakan salah satu sikap wirausaha yang sudah dapat memikirkan sesuatu yang baru dibandingkan pengusaha lainnya.

Telah dibuktikan dalam penelitian ini bahwa teori Sinaga tentang kreatifitas sudah diterapkan oleh ketiga informan dalam penelitian ini, yaitu Bapak Imam, Bapak Kawit dan Ibu Tri Kholipah. Mereka berhasil melahirkan ide untuk membuat sesuatu yang baru dibandingkan dengan pengusaha yang lainnya. Ketiga informan tersebut juga mencerminkan ciri-ciri pengusaha yang kreatif. Menurut Randsepp (dalam Rusdiana, 2014:59) ciri - ciri tentang pemikiran kreatif seorang pengusaha antara lain sensitif terhadap masalah, mampu menghasilkan ide besar, fleksibel, terbuka, mempunyai motivasi, mampu berkonsentrasi, dan mempunyai kemampuan memilih

Selain perilaku kreatif petani belimbing di Kelurahan Karangsari juga menerapkan perilaku inovatif dengan menciptakan produk olahan buah belimbing yang memiliki nilai jual. Sejalan dengan pernyataan Rusdiana (2014:107) yang menyatakan juga bahwa kemampuan inovasi merupakan proses mengubah peluang suatu gagasan dan ide-ide yang dapat dijual.

Teori lainnya yang mendukung penelitian ini yaitu dari Rusdiana (2014:112), yang menyatakan bahwa ada 4 jenis inovasi dan salah satunya pengembangan (Ekstensi), yaitu seseorang yang melakukan pemanfaatan lain pada produk atau jasa. Inovasi dapat dilakukan dengan mengembangkan produk yang telah dibuat. Seperti dalam penelitian ini yang menunjukkan ketiga informan melakukan pengembangan terhadap produk olahan belimbing yang mereka ciptakan. Seperti merubah ukuran, bentuk dan kemasan agar lebih menarik untuk dijual. Selain itu, mereka juga melakukan inovasi dalam hal pengurangan upaya dengan melakukan pemasaran secara online dan offline serta pemasaran dalam event event tertentu di Kota Blitar.

Menurut Philip Kotler (2003:30) terdapat beberapa pendekatan dalam inovasi produk antara lain :

1. Inovasi berbasis modulasi

2. Inovasi berbasis ukuran

3. Inovasi berbasis kemasan

4. Inovasi berbasis desain

5. Inovasi berbasis pengembangan bahan komplementer

6. Inovasi berbasis pengurangan upaya.

Kegiatan pengembangan produk yang dilakukan oleh ketiga informan tersebut mencerminkan pendekatan dalam inovasi produk yang dikemukakan oleh Philip Kotler

\section{PENUTUP}

Berdasarkan hasil penelitian dan pembahasan dapat disimpulkan bahwa 3 petani belimbing di Kelurahan Karangsari Kecamatan Sukorejo Kota Blitar melakukan perilaku kreatif dan inovatif dalam membudidayakan buah belimbing. Perilaku kreatif ditunjukkan dengan sensitif terhadap masalah, menghasilkan ide, memiliki motivasi, dan terbuka. Perilaku inovatif petani belimbing tersebut ditunjukkan dengan menghasilkan produk dan mengembangkan produk olahan belimbing dengan melakukan inovasi berbasis 
modulasi, inovasi berbasis ukuran, inovasi berbasis kemasan, dan inovasi berbasis pengurangan upaya.

Saran : Berdasarkan hasil penelitian dapat diajukan saran bahwa peluang usaha dapat tercipta dari berbagai sumber. perilaku kreatif dan inovatif akan sia-sia apabila tidak ada dukungan dari pemerintah dalam mengembangkan produk unggulan tersebut.

\section{DAFTAR PUSTAKA}

Kotler, P dan Fernando, T. D. B.2003. Lateral Marketing : New Techniques for Finding Breakthrough Ideas. Canada: John Wiley \& sons, Inc. Terjemahan Oleh E. Salim. 2004. Lateral Marketing: Berbagai Teknik Baru untuk mendapatkan ide-ide Terobosan.Jakarta: PT Penerbit Erlangga.

Rusdiana,MM. 2014. Kewirausahaan Teori dan Praktik. Bandung: CV Pustaka Setia

Suryana.2014. Kewirausahaan (Kiat Sukses dan Proses Menuju Sukses). Jakarta: Salemba Empat.

Yunitasari. 2013. Inovasi Produk Dalam Meningkatkan Minat Beli Konsumen Pada Pia Warung Glen more Banyuwangi. Universitas Jember

Wulandari, Hesty Wiyatmi. 2015. Perilaku Kreatif dan Inovatif Pengrajin Sepatu Kulit Di Dusun Genengan Kabupaten Mojokerto. Universitas Jember. 